\title{
PERILAKU RISIKO DALAM MEKANISME TRANSMISI KEBIJAKAN MONETER DI INDONESIA
}

\author{
Doni Satria' \\ Solikin M. Juhro*
}

\begin{abstract}
This study explores interconnections between risk behaviour in the financial sector, particularly banking sector, with monetary policy stance. Referring Bernanke and Blinder (1988) modified model for analyzing the bank credit behavior, we develop an empirical model to test the role of risk behaviour in monetary policy transmission mechanism. Vector Error Correction Model are applied to test the significance of interaction between risk variables and monetary policy stance in the short run dynamics of credit behavior around its long-run cointegration with real GDP. Some empirical results emerge from this preliminary study. First, there is early indication that risk taking channel in the monetary policy transmission mechanism exists in Indonesia during analysis period. Second, risk variables and credit tend to move procyclicalyl while monetary policy stance tends to a-cyclical. Third, pro-cyclical behavior of credit and risk variables reverses the effect of loose monetary policy stance, and there is an indication of asymmetric effect between tight monetary policy and loose monetary policy in Indonesian economy. These empirical findings bring about policy recommencations for better understanding on the risk behavior in the banking sector, as well as integration beetween monetary dan financial sector policies.
\end{abstract}

JEL Code : E52, E58,

Key word: Monetary Policy Transmission Mechanism, Monetary Policy Stance, Banking Risk Behavior, Risk Perception.

1 Staf Pengajar pada Fakultas Ekonomi Universitas Negeri Padang.

** Peneliti Ekonomi Bank Indonesia dan Staf Pengajar Program Pascasarjana Fakultas Ekonomi Universitas Indonesia. Penelitian ini merupakan pandangan pribadi dan tidak mewakili pandangan institusi dimana penulis bekerja. 


\section{PENDAHULUAN}

Pengaruh perilaku risiko pada dinamika sektor keuangan merupakan isu penelitian yang cukup mengemuka dewasa ini, khususnya dikaitkan dengan efektivitas respon kebijakan yang diambil terhadap krisis keuangan global yang terjadi semenjak pertengahan 2007. Beberapa argumen dibangun untuk melihat faktor penyebab mendasar di balik krisis keuangan yang ditengarai sebagai unprecedented crisis, baik dari segi besarnya pengaruh maupun waktu berlalunya. Taylor (2009) mengemukakan bahwa krisis disebabkan oleh kebijakan bank sentral yang cenderung mempertahankan tingkat bunga terlalu rendah, sebagai konsekuensi rendahnya tingkat inflasi dalam jangka waktu yang cukup panjang sebelum terjadi krisis. Taylor memaparkan bahwa bank sentral di negara maju tidak memperhitungkan risiko di sektor perbankan dan keuangan dalam fungsi reaksi kebijakan moneternya, sehingga menyebabkan penetapan tingkat bunga nominal yang salah (terlalu rendah). Implikasi dari analisis ini menunjukan adanya interaksi antara stance kebijakan moneter yang dilakukan oleh bank sentral terhadap risiko di sektor keuangan khususnya perbankan. Sedangkan Mishkin (2009) mengemukakan bahwa kebijakan moneter cenderung menjadi lebih potensial dimasa krisis tingkat efektifitasnya dibandingkan dengan kondisi normal, sehingga memberikan landasan untuk melakukan menejemen risiko makroekonomi untuk menghadapi masalah kontraksi perekonomian selama periode krisis.

Fakta di atas menunjukkan bahwa terdapat keterkaitan antara stabilitas moneter dengan stabilitas sektor keuangan. Bagaimana otoritas moneter harus merespon dan bertindak dalam menjalankan kebijakan moneternya umumnya dapat dipahami, dan relatif tidak banyak diperdebatkan di kalangan ahli ekonomi. Namun demikian, dalam hal bagaimana otoritas moneter harus merespon dan bertindak untuk permasalahan yang muncul dari sisi sektor keuangan masih menjadi perdebatan di kalangan ahli ekonomi (Goodhart dan Tsomocos, 2007). Bagi otoritas moneter, target kebijakan moneter yang dijalankan akan menjadi lebih mudah tercapai jika stabilitas sektor keuangan berkerja dengan baik. Sedangkan jika kondisi fundamental makroekonomi tidak stabil, akan menyebabkan gejolak pada sektor keuangan dalam perekonomian.

Keterkaitan antara stabilitas moneter dengan stabilitas sektor keuangan akhirnya menajdi isu sentral dalam upaya untuk melihat keterkaitan antara kebijakan yang diambil, perilaku risiko, dan berlangsungnya suatu krisis keuangan. Penelitian oleh Nier dan Zicchino (2008) mengemukakan bahwa penawaran kredit perbankan dipengaruhi oleh stance kebijakan moneter yang berinteraksi dengan tekanan pada neraca bank (balance sheet stress) yang ditransmisikan melalui kerugian bank. Penelitian yang menyimpulkan bahwa dampak interaksi stance kebijakan moneter dengan kerugian bank menjadi lebih kuat dalam periode krisis, dengan asumsi bahwa besaran risiko sektor keuangan semakin tinggi pada kondisi ekonomi sedang dalam kondisi 
krisis, mengimplikasikan bahwa faktor risiko sektor keuangan berinteraksi dengan stance kebijakan moneter. Untuk kasus Kanada, Li dan St-Amant (2010) menemukan bahwa kebijakan moneter ketat atau kontraktif memiliki dampak yang lebih kuat terhadap output dibandingkan dengan kebijakan moneter yang ekspansif, dan kebijakan moneter yang ekspansif memiliki dampak yang lebih kuat dibandingkan kebijakan moneter yang kontraktif saat perekonomian dalam kondisi tekanan keuangan (risiko) yang tinggi.

Selanjutnya, Borio (2008) mengemukakan pentingnya analisis jalur pengambilan risiko (risk taking channel) dalam mekanisme transmisi kebijakan moneter. Hal ini berbeda dengan jalur bank lending yang dikemukakan oleh Bernanke dan Blinder (1988) dan Bernanke dan Gertler (1995) yang mengemukakan bahwa kebijakan moneter bekerja melalui cadangan bank (bank reserve) dan selanjutnya mempengaruhi penawaran kredit perbankan dalam perekonomian. Risk taking channel mempengaruhi penawaran kredit oleh perbankan melalui keputusan bank untuk menyalurkan kredit berdasarkan perubahan perilaku bank dalam menghadapi risiko kredit. Adrian dan Shin (2009) mengemukakan bahwa risk taking channel ini juga berbeda dengan konsep tentang akselerator keuangan (financial accelerator) yang dikemukakan Bernanke dan Gertler (1999). Terkait dengan itu, hasil penelitian empiris cukup memberikan bukti tentang keberadaan risk taking channe/ dalam mekanisme transmisi kebijakan moneter. $^{2}$

Dalam konteks perekonomian Indonesia, pengamatan terhadap peran faktor risiko di sektor keuangan pada bekerjanya mekanisme transmisi belum dilakukan secara mendalam. Goeltom et al. (2009) secara umum menyimpulkan bahwa berdasarkan analisis empiris, persepsi risiko cukup berperan dalam mentransmisikan kebijakan moneter di Indonesia. Berdasarkan kondisi dan kompleksitas Bank Indonesia dalam menjalankan kebijakan moneter, penelitian ini mengindentifikasi permasalahan dampak asimetris dari kebijakan moneter. Kondisi asimetris tersebut dipengaruhi oleh perilaku sektor keuangan yang cenderung pro siklis dan keberadaan risk taking channel sebagaimana yang dikemukakan oleh Borio dan Zhu (2008). Hasil analisis yang dilakukan tersebut masih merupakan analisis awal dengan menggunakan swap premium sebagai indikator persepsi risiko secara umum. Hasil kajian tersebut menyarankan analisa lanjutan dengan menggunakan model analisis dan indikator yang lebih baik dan model empiris yang lebih mampu menangkap keberadaan peran risiko dan persepsi risiko di sektor keuangan dalam mentransmisikan kebijakan moneter di Indonesia.

Terkait dengan beberapa pemikiran di atas, sejalan dengan dinamika dan perubahan struktural dalam perekonomian Indonesia paska krisis ekonomi tahun 1998, pengelolaan

2 Lihat Gambacorta, 2009 dan Referensi dalam paper tersebut. 
stabilitas sektor keuangan dan moneter masih menghadapi permasalahan rigiditas tingkat bunga pinjaman yang disalurkan oleh perbankan ke perekonomian, dalam artian perkembangan suku bunga pasar keuangan belum sepenuhnya merepons perkembangan suku bunga kebijakan (BI Rate). Pengamatan menunjukan bahwa spread antara tingkat bunga kebijakan dengan cost of fund semakin menurun, namun pada saat yang bersamaan spread tingkat bunga kebijakan dengan suku bunga dasar kredit (SBDK) cenderung meningkat. SBDK memiliki berbagai komponen yang salah satu diantaranya adalah premi risiko perbankan (Bank Indonesia, 2010).

Paparan di atas secara tidak langsung mengindikasikan adanya interaksi antara kebijakan moneter dan risiko di sektor perbankan yang ditransmisikan ke perekonomian riil melalui penawaran kredit perbankan³. Indonesia sebagai sebuah negara yang belum memiliki sektor keuangan yang berkembang pesat seperti halnya di negara maju, tentunya belum memiliki alternatif pembiayaan investasi yang cukup luas dan peran sektor perbankan dalam sektor keuangan menjadi sangat dominan. Kajian untuk memahami bagaimana dampak risiko perbankan terhadap perekonomian Indonesia menjadi sangat penting dalam konteks untuk menjamin stabilitas sektor keuangan. ${ }^{4}$

Penelitian ini berusaha melihat keterkaitan antara risiko sektor keuangan, khususnya perbankan, dengan kebijakan moneter, serta implikasinya terhadap mekanisme transmisi kebijakan moneter ke sektor riil dalam perekonomian. Sampai saat ini sebagian besar analisis tentang stabilitas sektor keuangan terfokus pada pengidentifikasian faktor-faktor yang menentukan risiko sektor keuangan dan faktor kelembagaan yang menentukan profil risiko di sektor keuangan. Sedangkan bagaimana feedback dari perubahan risiko di sektor keuangan terhadap perekonomian riil masih belum banyak dimodelkan (Tieman dan Maechler, 2009). Dengan memahami besaran pengaruh perubahan risiko sektor keuangan, khususnya perbankan dan interaksinya dengan kebijakan moneter terhadap penawaran kredit perbankan, penelitian ini akan memberikan gambaran mengenai dampak riil perubahan risiko dan persepsi risiko di sektor perbankan serta kebijakan moneter (yang merupakan cerminan dari perilaku pengambilan risiko pelaku ekonomi) terhadap perekonomian.

3 Jalur kredit dalam mekanisme transmisi kebijakan moneter ini pertama kali dikembangkan oleh Bernanke dan Blinder (1988). Analisis mengenai bagaimana penawaran kredit bank dipengaruhi oleh kebijakan moneter dapat melalui berbagai jalur dalam dua dasawarsa terkahir telah banyak dianalisis oleh ekonom, dan merupakan sebuah penelitian aktif dalam ilmu ekonomi. Jalur transmisi kebijakan moneter melalui kredit perbankan yang telah dikemukakan sepengetahuan penulis antara lain, liquidity channel (Diamond dan Rajan, 2006), Bank Capital Channel (Van der Hauvel, 2007), Risk taking channel (Borio, 2008 dan Adrian dan Shin, 2009). Ketiganya bekerja mempengaruhi perekonomian riil melalui perubahan penawaran kredit sektor perbankan, yang selanjutnya mempengaruhi belanja riil investasi dan konsumsi.

4 Literatur yang berkembang menunjukan kecenderungan untuk menganalisis faktor apa yang mempengaruhi resiko perbankan, namun kurang memperhatikan bagaimana dampak faktor resiko perbankan terhadap perekonomian riil yang dalam hal ini ditransmisikan melalui penawaran kredit perbankan. 
Dalam penelitian ini dilakukan spesifikasi model empiris dengan melakukan modifikasi model yang dikembangkan Tieman dan Maechler (2009). Secara umum, model empiris akan menguji dampak perilaku risiko, tercermin pada indikator persepsi risiko (risk aversion) pelaku ekonomi dan tingkat risiko dalam industri perbankan, yang berinteraksi dengan stance kebijakan moneter pada penawaran kredit perbankan. Beberapa kesimpulan utama yang ditarik dari penelitian ini adalah bahwa persepsi risiko pelaku ekonomi dan tingkat risiko di sektor perbankan memiliki peran yang signifikan dalam mentransmisikan kebijakan moneter melalui jalur kredit di Indonesia. Dalam hal ini, peran persepsi risiko pelaku ekonomi dan tingkat risiko di sektor perbankan saat berinteraksi dengan stance kebijakan moneter menyebabkan pembalikan arah dampak kebijakan moneter yang longgar. Sebaliknya, stance kebijakan moneter yang ketat untuk mengkontraksi perekonomian melalui jalur kredit perbankan menjadi tidak efektif pada saat berinteraksi dengan variabel persepsi risiko pelaku ekonomi dan tingkat risiko di sektor perbankan.

Tulisan ini terdiri dari lima bagian. Menyambung latar belakang ini bagian kedua akan menyampaikan sekilas landasan teoritis terkait dengan keseimbangan pasar kredit dan peran variabel risiko sebagai faktor pendorong dan penarik dari ekspansi kredit perbankan. Bagian ketiga akan memaparkan metodologi penelitian, khususnya dalam pengembangan model empiris yang ditaksir dengan metode Vector Error Correction Model (ECM). Bagian berikutnya akan menyampaikan hasil penaksiran dan analisis dampak variabel risiko dan stance kebijakan moneter pada dinamika perkembangan kredit perbankan. Bagian penutup akan menyampaikan beberapa kesimpulan dan implikasi kebijakan.

\section{TEORI}

Bank atau lembaga perantara keuangan dalam perekonomian diyakini berperan sangat penting dalam mentransmisikan dampak kebijakan moneter oleh sebagian besar ahli ekonomi, namun bagaimana cara bank dalam mentransmisikan kebijakan moneter tersebut ke perekonomian riil masih belum memperoleh konsensus dari ahli ekonomi dan masih menjadi objek penelitian yang sangat penting dalam ilmu ekonomi moneter. Pendekatan awal dalam mejelaskan peranan bank dalam mentransmisikan kebijakan moneter diyakini melalui jalur uang atau kewajiban sektor perbankan terhadap perekonomian (money view), selanjutnya berkembang pemikiran bahwa bank mempengaruhi perekonomian melalui jalur kredit (Bernanke dan Blinder, 1988). Melalui jalur kredit diyakini bahwa kebijakan moneter bisa mempengaruhi perkonomian melalui penawaran kredit dari sektor perbankan atau bank lending channel, dan melalui neraca perusahaan dimana kebijakan moneter mempengaruhi kemampuan perusahaan 
dalam memperoleh sumber pembiayaan eksternal dari perbankan atau balance sheet channel (Bernanke dan Gertler, 1995).

Berdasarkan model teoritis awal yang dikembangkan oleh Bernanke dan Blinder (BB) tersebut, dapat dilakukan pengembangan model teoritis untuk memasukan peran risiko sektor keuangan khususnya dari sektor perbankan dalam menganalisis keberadaan jalur risiko dalam mekanisme transmisi kebijakan moneter. Pengembangan model dinamis sederhana berdasarkan model BB, seperti yang dikembangkan oleh Escandon dan Diaz-Bautista (2000) dan Walsh (1998) dapat dijadikan acuan dasar dalam mengembangkan model empiris yang akan digunakan dalam penelitian ini.

Dalam versi dinamis, kurva pemintaan komoditas dan kredit 'CC' dalam model BB ditransformasikan menjadi proses penyesuaian jangka pendek dan jangka panjang antara permintaan dan penawaran aggregat di sektor riil. ${ }^{5}$ Karena diasumsikan harga tetap, maka penyesuaian jangka pendek terjadi melalui mekanisme ekses demand yang menyebabkan output kembali ke kondisi keseimbangan. Kondisi ini dapat dituliskan sebagai berikut:

$$
\dot{y}=\beta\left(y^{d}-y\right) \quad \beta>0,
$$

Sebagaimana dalam model BB aggregat demand $\left(y^{d}\right)$ ditentukan oleh tingkat bunga kredit perbankan, tingkat bunga pasar, dan kebijakan fiskal. Sebagaimana juga dalam model $\mathrm{BB}$, tingkat bunga pasar ditentukan oleh kebijakan moneter (cadangan Bank, R) dan permintaan uang $\left(\mathrm{M}^{\mathrm{d}}\right)$, maka:

$$
\begin{array}{ll}
y^{d}=f(\rho, G, i) & f_{\rho}<0, f_{G}>0, f_{i}<0, \\
i=h\left(R, M^{d}\right) & h_{R}<0, f_{M d}>0,
\end{array}
$$

Dinamika sektor keuangan berasal dari pergerakan tingkat bunga kredit perbankan $(\rho)$ yang menyeimbangkan pasar kredit perbankan. Dengan asumsi tanpa ada credit rationing, variabel ini akan menyesuaikan ekses demand dan ekses penawaran di pasar kredit perbankan, sehingga:

$$
\begin{array}{ll}
\dot{\rho}=\alpha\left(L^{d}-L^{s}\right) & \alpha>0 \\
L^{d}=L\left(\rho, i, y, \sigma^{d}\right) & L_{\rho}<0, L_{i}>0, L_{y}>0, L_{\sigma} d<0
\end{array}
$$

5 Standar model IS-LM dalam buku teks makroekonomi menggunakan asumsi terdapat subtitusi yang sempurna antara bonds dengan kredit perbankan, model Bernanke dan Blinder (BB) melepas asumsi tersebut dan membentuk model keseimbangan IS-LM dengan memasukan pasar kredit bank dalam model. Dalam model BB permintaan kredit bank merupakan fungsi dari tingkat bunga pinjaman, tingkat bunga pasar (dengan demikian berarti tingkat bunga bonds) dan tingkat pendapatan, sehingga model ini menggunakan kurva CC sebagai pengganti kurva IS. (lihat Bernanke dan Blinder 1988) 


$$
L^{s}=\lambda\left(\rho, i, \sigma^{s}\right) \quad \lambda_{\rho}>0, \lambda_{i}<0, \lambda_{\sigma}<0
$$

Persamaan (II.4) sampai (II.6) menunjukan kondisi keseimbangan dalam pasar kredit perbankan melalui mekanisme penyesuian harga kredit perbankan (tingkat bunga kredit), permintaan kredit ditentukan oleh tingkat bunga kredit perbankan, tingkat bunga pasar pada bonds, tingkat perekonomian riil, dan risiko kredit dari sisi permintaan. Selanjutnya penawaran kredit perbankan dipengaruhi oleh tingkat bunga kredit perbankan, tingkat bunga pasar bonds dan tingkat risiko alokasi kredit perbankan.

Selain variabel risiko semua variabel yang dimasukan dalam model analisis yang dikembangkan berdasarkan model yang dikemukakan oleh Escandon dan Diaz-Bautista (2000) ini sama dengan model BB (1988). Dalam analisisnya Escandon dan Diaz-Bautista tidak menjelaskan landasan teoritis untuk memasukan variabel risiko permintaan dan penawaran kredit dalam model ini. Penjelasan lebih lanjut untuk menjustifikasi dimasukannya variabel risiko sebagai komponen yang mempengaruhi penawaran kredit perbankan yang kemudian berinteraksi dengan kebijakan moneter dikembangkan oleh Freixas dan Jorge (2008) dan Disyatat (2010).

Dinamika model yang direpresentasikan oleh persamaan (II.1) sampai (II.6) dapat dijelaskan sebagai berikut. Dengan melakukan linearisasi pada kondisi keseimbangan jangka panjang masing-masing variabel menggunakan first order Taylor expansion series akan diperoleh dinamika dari sektor riil dengan menggunakan persamaan (II.1) sampai (II.4) sebagai berikut:

$$
\dot{y}=-\beta(y-\bar{y})+\beta f_{\rho}(\rho-\bar{\rho})+\beta f_{G}(G-\bar{G})+\beta f_{i}(i-\bar{i})
$$

Karena diasumsikan dalam persamaan (II.1) $\beta>0$, maka $\dot{y}$, akan stabil. Sehingga secara grafis hubungan $y$ dengan pertumbuhan $y$ dapat digambarkan sebagai berikut:

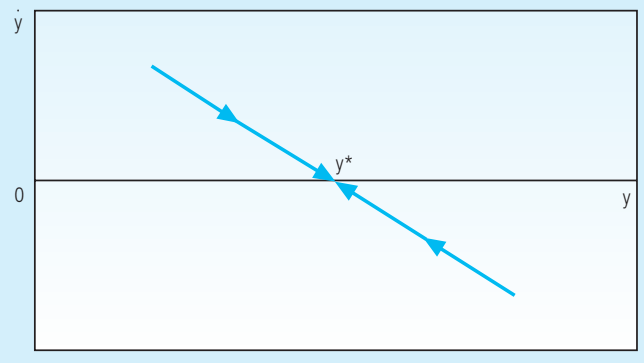

Grafik 1.

Dinamika Pertumbuhan Sektor Riil 
Grafik 1, menunjukan hubungan antara perubahan variabel y (output perekonomian) dari waktu ke waktu $\left(\partial_{y} / \partial_{t}\right)$ dengan variabel $y$. Karena $\beta>0$, maka hubungan antara perubahan $y$ terhadap $t$ dengan $y$ adalah negatif. Dengan demikian pada saat pertumbuhan nilai output perekonomian lebih besar dari nol, maka nilai y akan terus meningkat ( $y$ bergerak dari kiri ke kanan), sebaliknya jika pertumbuhan nilai output lebih kecil dari nol, maka nilai $y$ akan menurun dan bergerak dari kiri ke kanan. Karena hubungan negatif antara pertumbuhan $y$ dengan nilai $y$, maka pada saat di titik $y^{*}$ nilai $y$ akan stabil. Dengan melakukan langkah yang sama, maka dinamika sektor keuangan adalah:

$$
\begin{aligned}
\dot{\rho}= & \alpha L_{y}(y-\bar{y})+\alpha\left(L_{\rho}-\lambda_{\rho}\right)(\rho-\bar{\rho})+\alpha\left(L_{i}-\lambda_{i}\right)(i-\bar{i}) \\
& +\alpha L_{\sigma^{d}}\left(\sigma^{d}-\bar{\sigma}^{d}\right)-\alpha \lambda_{\sigma^{s}}\left(\sigma^{s}-\bar{\sigma}^{s}\right)
\end{aligned}
$$

Karena $\alpha>0\left(L_{\rho}, \lambda_{\rho}\right)<0$ dan, maka $\dot{\rho}$ akan stabil:

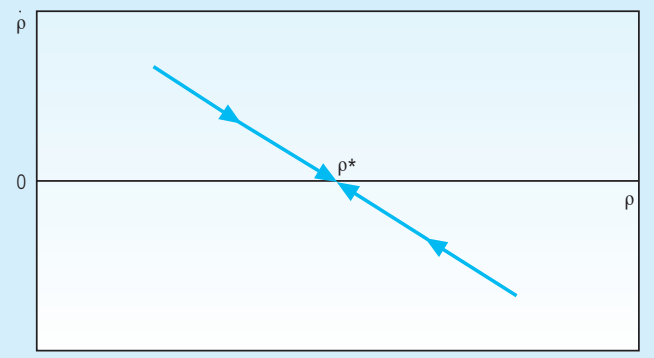

Grafik 2.

Dinamika Perubahan Sektor Keuangan

Berdasarkan grafik 2. Dengan asumsi $\left(L_{\rho}-\lambda_{\rho}\right)<0$, maka hubungan antara $\rho$ dengan $\dot{\rho}$ akan negatif. Untuk setiap nilai positif ataupun negatif dari $\dot{\rho}$ akan menyebabkan nilai $\rho$ turun atau naik (semakin besar atau semakin kecil). Akibatnya dalam jangka panjang nilai $\rho$ akan konstan pada saat $\dot{\rho}=0$ pada titik $\rho^{*}$. Grafik 1 dan grafik 2 menunjukan proses menuju keseimbangan dalam pasar barang dan jasa dan pasar kredit perbankan. Dalam model yang digunakan oleh BB (1988) perubahan eksogen dalam keseimbangan di pasar kredit (dengan tidak sempurnanya subtitusi antara pasar kredit dan pasar modal) dapat merubah keseimbangan pada perekonomian.

Selanjutnya dalam mengembangkan hipotesis untuk mengetahui bagaimana dampak masing-masing varibel terhadap perubahan eksogen dari variabel risiko dalam penyaluran kredit 
perbankan digunakan solusi matriks untuk kedua persamaan dalam sistem persamaan diferensial tersebut:

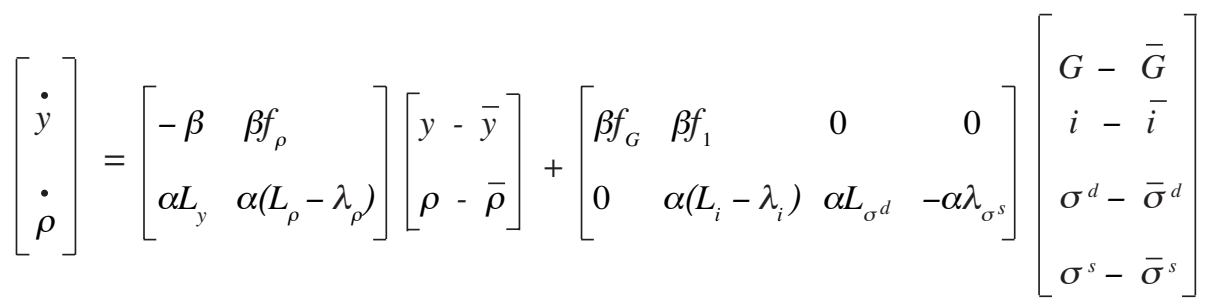

Representasi grafis menggunakan phase diagram pergerakan dinamis pada variabel tingkat bunga kredit perbankan dan pendapatan (PDB) disampaikan pada grafik 3. Grafik 3 adalah hasil penggabungan grafik 1 dan grafik 2 yang dapat dianalisis dalam dua sumbu yang menunjukan hubungan antara $y$ dan $\rho$ pada saat $\dot{\rho}$ dan $\dot{y}$ sama dengan nol. Berdasarkan persamaan II.7 dan II.8, pada saat keseimbangan di titik $\rho^{*}$ hubungan antara $\rho$ dan $y$ adalah positif, dan pada titik $y^{*}$ hubungan antara $\rho$ dan $y$ adalah negatif. Dengan menggunakan penjelasan yang dilakukan pada grafik 1 dan grafik 2, maka untuk tiap kondisi perekonomian yang tidak dalam keseimbangan pada pasar kredit dan pasar barang dan jasa, perekonomian akan menuju keseimbangan dalam jangka panjang pada titik $\rho^{\star}$ dan $y^{*}$. Dalam model ini menunjukan bahwa perubahan eksogen pada variabel $G, i$ (tingkat bunga di pasar modal), $\sigma^{d}$ (risiko sektor keuangan di sisi permintaan) dan $\sigma^{s}$ (risiko sektor keuangan di sisi supply) akan menyebabkan pergeseran dari equilibrium dalam jangka panjang melalui perubahan/pergeseran keseimbangan dalam model (titik $\mathrm{e}_{0}$ ).

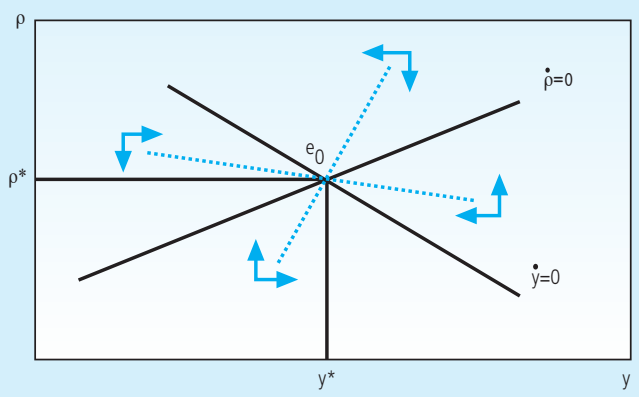

Grafik 3.

Dinamika Keseimbangan Umum

Dalam Perekonomian 
Berdasarkan hasil penjelasan grafis menunjukkan bahwa model yang dikembangkan ini secara dinamis stabil dan mengindikasikan bahwa perekonomian akan menuju kepada keseimbangan jangka panjang. Landasan teoritis dalam model ini dapat diperoleh solusinya sebagai alat untuk membentuk hipotesis dari teori ekonomi yang akan diuji dengan menggunakan model empiris. Dalam jangka panjang, variabel ekonomi akan menuju keseimbangan yang baru setelah adanya shock yang terjadi pada variabel eksogen. Dalam model ini yang merupakan variabel eksogen adalah kebijakan fiskal (G), Kebijakan moneter (R) dan variabel risiko ( $\sigma$ ). Dampak parsial dari masing-masing variabel eksogen adalah sebagai berikut:

$$
\left.\frac{\partial_{y}}{\partial G}\right|_{y^{\circ}=0}=f_{G}>0 \quad ;\left.\quad \frac{\partial_{y}}{\partial_{G}}\right|_{\rho^{\prime}=0}=0
$$

Kenaikan pengeluaran pemerintah (kebijakan fiskal) memiliki dampak positif terhadap keseimbangan jangka panjang PDB (output) secara langsung melalui peningkatan permintaan riil dalam perekonomian, karenanya kurva $\dot{y}=0$ harus bergeser kekanan. Sedangkan kurva $\dot{\rho}=0$ tidak terpengaruh karena belanja pemerintah (G) tidak secara langsung mempengaruhi sektor keuangan.

$$
\left.\frac{\partial y}{\partial i}\right|_{\dot{y}=0}=f_{i}<0 ;\left.\quad \frac{\partial y}{\partial i}\right|_{\dot{\rho}=0}=\frac{-\left(L_{i}-\lambda_{i}\right)}{L_{y} \cdot}<0
$$

Berdasarkan asumsi dalam persamaan (II.3), kebijakan moneter yang dilakukan Bank Sentral, misalnya dengan melakukan pembelian surat berharga dengan instrumen operasi pasar terbuka, akan meningkatkan jumlah cadangan bank. Kebijakan tersebut akan meningkatkan penawaran kredit perbankan, menurunkan biaya pinjaman dana dari bank, sehingga mendorong peningkatan produksi dalam perekonomian. Agar kondisi tersebut tercapai maka kurva $\dot{y}=0$ dan $\dot{\rho}=0$ harus bergeser kekanan dan pergeseran pada kurva $\dot{\rho}=0$ secara proporsional harus lebih besar.

$$
\begin{aligned}
& \left.\frac{\partial y}{\partial \sigma^{s}}\right|_{\dot{y}=0}=0 \quad ;\left.\quad \frac{\partial y}{\partial \sigma^{s}}\right|_{\dot{\rho}=0}=\frac{\lambda_{\sigma^{s}}}{L_{y}}<0 \\
& \left.\frac{\partial y}{\partial \sigma^{d}}\right|_{\dot{y}=0}=0 \quad ;\left.\quad \frac{\partial y}{\partial \sigma^{d}}\right|_{\dot{\rho}=0}=\frac{-L_{\sigma^{d}}}{L_{y}}>0
\end{aligned}
$$


Guncangan eksogen yang bersumber pada perubahan risiko dari penawaran dan permintaan kredit perbankan dalam model ini memiliki implikasi penting terhadap perekonomian yang ditransmisikan melalui pergeseran kondisi keseimbangan dalam pasar kredit perbankan. Jika terjadi peningkatan risiko yang dihadapi oleh perbankan, maka risiko di sisi penawaran kredit perbankan akan meningkat, meningkatkan biaya kredit perbankan, sehingga menurunkan tingkat produksi (PDB atau output) perekonomian dalam jangka panjang. Secara grafis kondisi ini dapat digambarkan sebagai pergeseran pada kurva $\dot{\rho}=0$.

Selanjutnya Freixas dan Jorge (2008), mengembangkan model teoritis bekerjanya mekanisme transmisi kebijakan moneter melalui risiko dengan menggunakan pendekatan partial equilibrium dalam pasar uang antar bank. Secara garis besar dalam model ini dijelaskan kebijakan moneter yang dijalankan oleh Bank Sentral akan mempengaruhi ketersediaan likuiditas di pasar uang antar bank, selanjutnya memaksa bank yang kekurangan likuiditas merasionalisasi kredit yang diberikan kepada nasabahnya (terjadi credit rationing), sehingga akan menyebabkan peningkatan ataupun penurunan produksi di sektor riil. Informasi yang tidak sempurna dalam pasar uang antar bank merupakan sumber munculnya risiko yang ada dalam pasar uang antar bank. Sehingga menyebabkan dampak kebijakan moneter yang diberlakukan memiliki besaran yang lebih besar dibandingkan kondisi jika ada informasi yang sempurna dalam mekanisme pasar uang antar bank tersebut. Model teoritis ini memberikan justifikasi bekerjanya mekanisme transmisi kebijakan moneter melalui jalur kredit perbankan tanpa harus menggunakan asumsi tidak ada perilaku credit rationing dalam pasar kredit perbankan. Sehingga hipotesis yang dihasilkan berdasarkan solusi dalam versi dinamis model BB sebelumnya tetap bisa digunakan dalam penelitian ini.

Pengembangan model risiko pada dalam jalur kredit dalam mekanisme kebijakan moneter yang dikemukakan Disyatat (2010) juga menghasilkan kesimpulan yang relatif sama dengan model yang dikemukakan oleh Freixas dan Jorge (2008). Dalam model tersebut dikemukakan bahwa mekanisme risiko berperan sebagai faktor pendorong dan penarik dari ekspansi kredit perbankan. Kesimpulan yang dihasilkan oleh kedua model ini berbeda dengan kesimpulan awal yang dikemukakan oleh model Bernanke dan Blinder (1988). Pada model BB, kebijakan moneter bekerja mempengaruhi jumlah pinjaman yang disalurkan perbankan melalui penurunan jumlah deposit (dan cadangan bank) yang dapat dikumpulkan oleh bank untuk disalurkan sebagai kredit ke dunia usaha. Sedangkan dalam kedua model ini, karena fakta empiris dalam perekonomian yang menunjukan bahwa bank bisa mendapatkan sumber dana lain selain deposit (misalnya melalui pinjaman antar bank), maka mekanisme kerja dalam kebijakan moneter untuk mempengaruhi pinjaman bank adalah melalui perubahan risiko yang dihadapi oleh bank dalam memperoleh sumber pendanaan dari pasar uang antar bank. Sedangkan pembentukan deposit 
dalam model Disyatat (2010) disebabkan oleh penyaluran kredit oleh perbankan (inside money). Kesimpulan model ini menunjukan bahwa peran bank lending dalam transmisi kebijakan moneter menjadi penting dalam perekonomian walaupun peran sektor keuangan non bank sebagai alternatif sumber dana investasi selain bank sudah maju.

\section{METODOLOGI}

\subsection{Dampak Riil Risiko Perbankan dan Kebijakan Moneter pada Perekonomian}

Berdasarkan kajian teoritis menunjukan bahwa kebijakan moneter memiliki dampak riil terhadap perekonomian melalui peranan kredit perbankan. Selanjutnya literatur mekanisme transmisi kebijakan moneter menunjukan bahwa peranan sektor keuangan dalam mempengaruhi perekonomian adalah melalui jalur kredit yang disalurkan perbankan ke sektor riil. Berdasarkan hasil kajian teoritis menunjukan bahwa terdapat hubungan jangka panjang antara kredit yang disalurkan perbankan dengan perekonomian, yang dalam tataran permodelan empiris mengindikasikan adanya kointegrasi antara jumlah kredit riil yang disalurkan sektor perbankan dengan produksi riil dalam perekonomian.

Implikasi dari model teoritis yang dikembangkan menunjukan terdapat dinamika jangka pendek dalam perubahan perilaku risiko di penawaran kredit perbankan yang berinteraksi dengan kebijakan moneter. Kondisi ini mempengaruhi pergerakan kredit perbankan yang disalurkan oleh bank, sehingga perubahan perilaku risiko dari sisi penawaran kredit setidaknya dalam jangka pendek akan memiliki pengaruh terhadap perekonomian, melalui perubahan kredit riil yang disalurkan oleh sektor perbankan.

Dalam analisis empiris yang dilakukan dalam penelitian ini akan digunakan dua indikator perilaku risiko di sektor perbankan ini. Indikator pertama memberikan ukuran untuk tingkat risk averse dari pelaku sektor perbankan dalam pengelolaan aset dengan asumsi sudah secara optimal melakukan pengalokasian asetnya. Indikator kedua menunjukan tingkat risiko dalam industri perbankan.

Dengan demikian maka dapat digunakan spesifikasi model ekonometri dalam spesifikasi Error Correction Model (ECM) sebagai berikut:

$$
\begin{aligned}
\Delta \text { Cred }_{t}^{i}= & \alpha\left(\text { Cred }_{t-1}^{i},-\beta_{1} G D P_{t-1}-\beta_{2}\right)+\gamma_{1} \Delta G D P_{t-1}+\gamma_{2} \Delta \text { Cred }_{t-1}^{i}+\gamma_{3} \text { Risk }_{t}^{A}+\gamma_{4} \text { Risk }_{t}^{D D} \\
& +\gamma_{5, k} \text { Stance }_{t}^{k}+\gamma_{6, k}\left(\text { Risk }^{A} * \text { Stance }^{k}\right)_{t}+\gamma_{7, k}\left(\text { Risk }^{D D} * \text { Stance }^{k}\right)_{t}+\varepsilon_{t}
\end{aligned}
$$


$i=1,2,3$ (Kredit Investasi, Kredit Modal Kerja dan Kredit Konsumsi)

$k=1,2$ (Stance Kebijakan Moneter Ketat dan Stance Kebijakan Moneter Longgar)

$j=$ time lag, dan $t=$ time

Dimana:

Cred $\quad=$ Kredit riil yang disalurkan perbankan pada suku bunga keseimbangan pasar (Kredit Investasi, Modal Kerja dan Konsumsi)

GDP $\quad=$ Produksi Domestik Bruto riil

Risk $_{t}^{A} \quad=$ Indeks persepsi risiko pelaku di sektor perbankan

Risk ${ }_{t}{ }_{t} \quad=$ Tingkat Risiko Sektor Perbankan (Distance to Default)

Stance $^{k}=$ Ukuran stance kebijakan moneter (Ketat dan Longgar)

Persamaan (II.12) menunjukan perubahan kredit perbankan dipengaruhi hubungan jangka panjang antara dua variabel yang stasioner pada first difference, I(1), kredit perbankan riil dengan perekonomian riil, dimana koefisien kecepatan penyesuaian jangka panjangnya adalah $\alpha$. Selanjutnya dalam jangka pendek perubahan kredit dipengaruhi oleh pertumbuhan ekonomi pada tahun sebelumnya, indikator risiko sektor perbankan dan persepsi risiko pelaku di sektor perbankan, interaksi antara risiko perbankan dan persepsi risiko pelaku perbankan dengan indikator stance kebijakan moneter. Dengan asumsi teoritis bahwa dalam jangka panjang terdapat cointegrasi antara kredit dan PDB maka persamaan (II.12) akan diestimasi dengan menggunakan VECM, sebagaimana dikemukakan oleh Johansen. ${ }^{6}$ Keuntungan hasil estimasi dengan menggunakan model VECM adalah dimungkinkannya melihat dampak error correction term pada dinamika jangka pendek dalam interaksi dua arah antara kredit dan PDB dalam satu sistem permodelan. Dengan demikian, dapat diketahui apakah variabel kredit merupakan variabel yang weakly exogenous terhadap PDB. Jika hasil estimasi menunjukan kredit merupakan variabel yang weakly exogenous bagi dinamika jangka pendek PDB dalam mekanisme VECM yang digunakan, berarti tidak ada feedback yang terjadi dari perubahan kredit terhadap dinamika PDB.

Untuk melakukan estimasi pada persamaan (II.12), diperlukan indikator variabel risiko perbankan dan indikator variabel stance kebijakan moneter. Dalam penelitian ini dua indikator risiko akan dihitung dan digunakan sebagai variabel bebas pada persamaan (II.12). Indikator risiko yang digunakan adalah indikator risiko perbankan dan indikator persepsi risiko dari pelaku ekonomi di sektor perbankan. Sedangkan untuk indikator stance kebijakan moneter, digunakan selisih antara tingkat bunga optimal untuk kebijakan moneter (sesuai hasil perhitungan empiris untuk Indonesia), dengan tingkat bunga aktual. Jika kebijakan moneter terlalu ketat, maka tingkat bunga aktual akan lebih tinggi dibanding tingkat bunga optimal hasil estimasi, dan

6 Lihat Enders, 2004, hal 362-366. 
sebaliknya. Jika tingkat bunga aktual sama dengan tingkat bunga optimal hasil estimasi berarti kebijakan moneter bersifat netral. Estimasi tingkat bunga kebijakan moneter tersebut adalah dengan menggunakan Taylor Monetary Policy Rules, dimana model ini dan variasinya juga digunakan oleh Bank Indonesia untuk menganalisis kebijakan moneter di Indonesia.

Berdasarkan model ekonometri pada persamaan (II.12) dampak parsial variabel persepsi risiko pelaku di sektor perbankan terhadap dinamika kredit adalah

$$
\frac{\partial C r^{i}}{\partial \operatorname{Risk}^{A}}=\gamma_{3}+\gamma_{6, k} \text { stance }^{k}
$$

Pengujian hipotesis penelitian terhadap dampak variabel persepsi risiko pelaku di sektor perbankan terhadap dinamika jangka pendek kredit perbankan yang berinteraksi dengan stance kebijakan moneter dapat menggunakan:

$$
\mathrm{H}_{0}: \gamma_{3}+\gamma_{6, k}=0 \text { dan } \mathrm{H}_{1}: \gamma_{3}+\gamma_{6, k} \neq 0
$$

Nilai t-hitung untuk pengujian t-statistik pada hipotesa ini dapat dilakukan dengan cara:

$$
t=\frac{\gamma_{3}+\gamma_{6, k}}{\operatorname{se}\left(\gamma_{3}+\gamma_{6, k}\right)}
$$

Simpangan baku (standar error) dari persamaan (II.14) tidak dapat diketahui dengan menggunakan hasil estimasi persamaan (II.12), agar bisa mendapatkan nilai simpangan baku yang dibutuhkan dapat dilakukan dengan melakukan modifikasi sebagai berikut. ${ }^{7}$

Jika : $\gamma_{3}+\gamma_{6, k}=\theta$, maka $\gamma_{3}=\theta-\gamma_{6, k}$, maka, sehingga modifikasi persamaan (II.12) adalah:

$$
\begin{aligned}
& \Delta \operatorname{Cred}_{t}^{i}=\alpha\left(\text { Cred }_{t-1}^{i},-\beta_{1} G D P_{t-1}-\beta_{2}\right)+\gamma_{1} \Delta G D P_{t-1}+\gamma_{2} \Delta \operatorname{Cred}_{t-1}^{i}+\left(\theta-\gamma_{6, k}\right) \operatorname{Risk}_{t}^{A}+\gamma_{4} \operatorname{Risk}_{t}^{D D}
\end{aligned}
$$

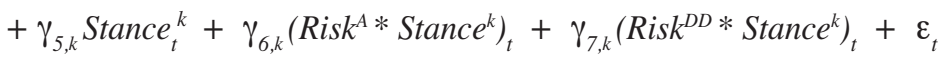

Sehingga:

$$
\begin{aligned}
\Delta \text { Cred }_{t}^{i}= & \alpha\left(\text { Cred }_{t-1}^{i},-\beta_{1} G D P_{t-1}-\beta_{2}\right)+\gamma_{1} \Delta G D P_{t-1}+\gamma_{2} \Delta \text { Cred }^{i}{ }_{t-1}+\theta \text { Risk }_{t}^{A}+\gamma_{4} \text { Risk }_{t}^{D D} \\
& +\gamma_{5, k} \text { Stance }_{t}^{k}+\gamma_{6, k}\left[\left(\text { Risk }^{A} * \text { Stance }^{k}\right)_{t}-\text { Risk }_{t}^{A}\right]+\gamma_{7, k}\left(\text { Risk }^{D D *} \text { Stance }^{k}\right)_{t}+\varepsilon_{t}
\end{aligned}
$$

Dengan menggunaan hasil estimasi simpangan baku yang diperoleh dari koefisien $q$ pada persamaan (II.15a), kita akan dapat melakukan pengujian hipotesis dengan menggunakan nilai statistik $t$ pada persamaan (II.14). Pengujian hipotesis dengan langkah dan cara yang sama

7 Lihat Wooldridge, 2005. Hal 148-149. 
dilakukan juga untuk menguji dampak parsial dari risiko sektor perbankan (DD) yang berinteraksi dengan stance kebijakan moneter.

Selanjutnya dampak parsial stance kebijakan moneter terhadap dinamika kredit jangka pendek adalah, $\frac{\partial C r^{i}}{\partial \text { Stance }^{k}}=\gamma_{5, k}+\gamma_{3}$ Risk $^{A}+\gamma_{4}$ Risk $^{D D}$

hasil ini tidak bisa dianalisa dengan menggunakan asumsi dampak stance kebijakan moneter pada saat besarnya variabel risiko sama dengan nol. Dengan menggunakan rata-rata besarnya nilai variabel risiko dalam sample yang digunakan, maka hasil estimasi untuk dampak stance kebijakan moneter yang diperoleh adalah dampak stance kebijakan moneter pada saat besarnya nilai variabel risiko sebesar rata-ratanya. Pengujian hipotesis untuk dampak stance kebijakan moneter ini juga dapat menggunakan teknik yang sama dengan pengujian untuk dampak variabel risiko yang telah dijelaskan sebelumnya. Jika hasil pengujian untuk dampak parsial stance kebijakan moneter yang berinteraksi dengan variabel risiko signifikan, mengindikasikan adanya bukti mekanisme transmisi kebijakan moneter melalui jalur risiko dalam perekonomian Indonesia selama periode analisis.

\subsection{Indikator Perilaku Risiko di Sektor Perbankan}

Sebagaimana telah disinggung sebelumnya, penelitian ini menggunakan dua indikator perilaku risiko di sektor perbankan. Indikator pertama memberikan ukuran untuk tingkat risk averse dari pelaku sektor perbankan dalam pengelolaan aset dengan asumsi sudah secara optimal melakukan pengalokasian asetnya. Indikator kedua menunjukan tingkat risiko dalam industri perbankan secara keseluruhan.

\subsubsection{Indikator Persepsi Risiko Pelaku Sektor Perbankan}

Indikator persepsi risiko adalah indikator yang akan menjelaskan perilaku bank dalam menilai risiko berdasarkan teori alokasi aset yang meminimalkan risiko dengan asumsi bank berperilaku risk averse. Dengan mengasumsikan bank mengalokasikan portfolio dalam bentuk aset tidak berisiko sebesar 1-y, maka return dari total portofolio bank adalah (Bodie. et.al, 2009):

$$
r_{c}=y r_{p}+(1-y) r_{f}
$$

$$
\text { Dimana: } \begin{aligned}
r_{c} & =\text { Return dari total portofolio bank } \\
r_{p} & =\text { Return dari portofolio yang berisiko } \\
r_{f} & =\text { Return dari portofolio yang tidak berisiko }
\end{aligned}
$$


Dengan menggunakan operator ekspektasi terhadap persamaan (II.16), ekspektasi terhadap total return dari alokasi portofolio yang berisiko dan tidak berisiko, adalah:

$$
E\left(r_{c}\right)=r_{f}+y\left[E\left(r_{p}\right)-r_{f}\right]
$$

Dengan menggunakan asumsi fungsi utility dari bank berdasarkan ekspektasi terhadap return dari portofolio yang dialokasikan oleh bank sebagai berikut (Bodie, et.al, 2009, halaman 157):

$$
U=E\left(r_{c}\right)-{ }^{1} /{ }_{2} A \sigma_{c}^{2}
$$

Dimana $U$ adalah utility, $r$ adalah return dari portfolio, $A$ adalah indeks dari risk aversion bank, dan $\sigma_{c}^{2}$ adalah varian dari return of asset. Selanjutnya menggunakan persamaan (II.17) dapat diketahui variance dari total aset adalah:

$$
\sigma_{c}^{2}=y^{2} \sigma_{p}^{2}
$$

Maka alokasi optimal dari aset yang dilakukan oleh bank adalah dengan memaksimumkan nilai utility adalah:

$$
\operatorname{Max} U=E(r)-{ }^{1} /{ }_{2} A \sigma_{c}^{2}=r_{f}+y\left[E\left(r_{p}\right)-r_{f}\right]-{ }^{1} / 2 A y^{2} \sigma_{p}^{2}
$$

Solusi untuk alokasi aset yang optimal bagi bank adalah:

$$
y^{*}=\frac{E\left(r_{p}\right)-r_{f}}{A \sigma_{p}^{2}}
$$

Sehingga koefisien perilaku bank dalam menentukan risk aversion adalah sebagai berikut:

$$
A=\frac{E\left(r_{p}\right)-r_{f}}{y^{*} \sigma_{p}^{2}}
$$

Dimana:

A $\quad=$ Koefisien Risk Aversion Bank

$E\left(r_{p}\right)-r_{f}=$ Risk premium (selisih expected return portfolio yang berisiko dengan return aset yang tidak berisiko).

$y^{*} \quad=$ Jumlah aset bank yang berisiko (selain SBI dan SUN)

$\sigma_{p}^{2} \quad=$ Varian dari aset return

\subsubsection{Indikator Tingkat Risiko di Sektor Perbankan}

Selain menggunakan indikator persepsi risiko yang telah dijelaskan di atas, dalam penelitian ini juga menggunakan indikator risiko lain, indikator tingkat risiko sektor perbankan. Jika nilai 
pasar sebuah perusahaan lebih rendah dari nilai kewajibannya, maka perusahaan itu dinyatakan bankrut/default. Dengan menggunakan konsep ini, risiko sebuah perusahan (termasuk bank), dapat diketahui dengan memanfaatkan informasi seberapa jauh jarak antara kondisi rasio nilai pasar aset bank terhadap kewajiban bank yang ada dengan kondisi terjadi default. Menggunakan teori yang dikembangkan oleh Merton (1974) untuk mengetahui Distance to Default, Vassalou dan Xing (2004) menggunakan rumusan sebagai berikut:

$$
D D_{t}=\frac{\ln \left(V_{A, t} / X_{t}\right)+\left(\mu-\sigma_{A}^{2}\right) T}{\sigma_{A} \sqrt{T}}
$$

Dimana:

$D D_{t} \quad=$ Distance to default

$V_{A, t} \quad=$ Nilai pasar dari aset

$X_{t} \quad=$ Total Kewajiban

$\mu \quad=$ Rata-rata Pertumbuhan Nilai Aset

$\sigma_{A}=$ Simpangan baku dari nilai pasar aset.

$T=$ Waktu jatuh tempo dari utang perusahaan

$D D$ menyatakan berapa standar deviasi penyimpangan dari nilai rata-rata yang diperlukan oleh rasio nilai pasar aset terhadap kewajiban untuk sebuah perusahaan mengalami default atau dapat dinyatakan default (Vassalou dan Xing, 2004). Bank merupakan jenis perusahaan yang memiliki aturan yang sangat ketat serta memiliki struktur aset dan kewajiban yang berbeda dengan perusahaan pada umumnya. Sebuah bank akan memiliki kewajiban yang jauh lebih besar dari perusahaan lainnya karena mengelola dana dari masyarakat. Sebagai akibatnya perhitungan yang digunakan untuk mengetahui indikator DD sebuah bank juga harus disesuaikan. Karena metode yang dikemukakan oleh Vassalou dan Xing (2004) adalah metode yang digunakan untuk perusahaan secara umum dan bukan yang khusus digunakan untuk bank, maka rumusan perhitungan nilai DD harus dimodifikasi sebagaimana yang dikemukakan oleh (Chan-Lau dan Sy, 2007) sebagai berikut:

$$
D D_{t}=\frac{\ln \left(V_{A, t} / \lambda X_{t}\right)+\left(\mu-\sigma_{A}^{2}\right) T}{\sigma_{A} \sqrt{T}}
$$

Dimana:

$D D_{t} \quad=$ Distance to Capital

$$
\lambda=\frac{1}{1-P C A R_{i}}
$$

PCAR = Minimum CAR (Rasio Modal Minimum) sesuai dengan regulasi perbankan 
Berdasarkan persamaan (II.24), secara implisit dalam persamaan (II.23) menunjukan nilai $\lambda=1$. Implikasinya persamaan (II.24) bukan lagi merupakan nilai distance to default tetapi merupakan distance to capital yang merupakan ukuran solvency dari sebuah bank.

Grafik 4 menunjukkan hasil penghitungan indikator perilaku risiko. Dapat dilihat bahwa perilaku resiko pelaku ekonomi (indikator risk aversion) dan tingkat risiko di sektor perbankan (distance to default - inverse) cenderung rendah saat risk premium, yang ditaksir dari selisih suku bunga kredit dan suku bunga kebijakan (SBI 1 bulan), tinggi dan sebaliknya. Kondisi ini mengindikasikan bahwa pelaku ekonomi sektor perbankan akan merespon pengetatan kebijakan moneter dengan mengalokasikan dana yang dikelola ke portfolio yang relatif kurang beresiko. Sedangkan pada saat tingkat bunga kebijakan moneter cenderung rendah, risk premium yang tinggi mampu mengurangi efek tingginya persepsi resiko mereka terhadap perilaku mereka dalam pengalokasian dana yang dikelola.

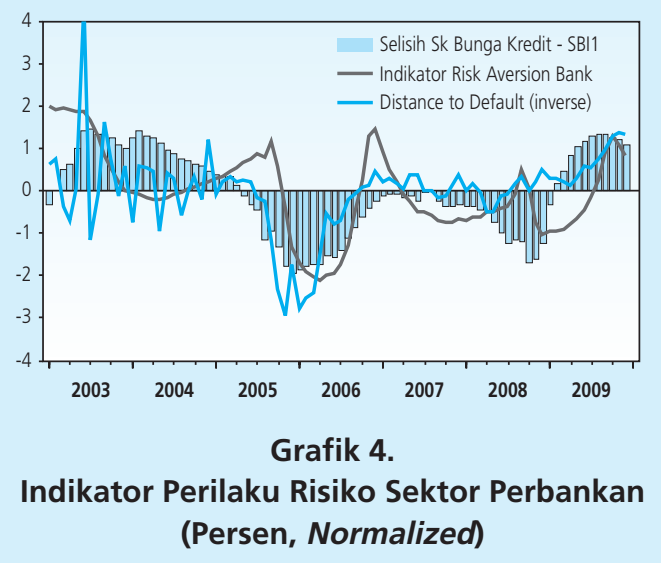

\subsection{Indikator Stance Kebijakan Moneter}

Agar persamaan (II.12) dapat diestimasi, diperlukan indikator stance kebijakan moneter. Stance kebijakan moneter yang digunakan sebagai variabel penjelas untuk dinamika kredit perbankan jangka pendek dalam penelitian ini adalah selisih antara tingkat bunga kebijakan aktual (SBI rate) dengan hasil estimasi menggunakan aturan kebijakan moneter (Monetary Policy Rules). Mengikuti Juhro (2009), dalam penelitian ini menggunakan data stance kebijakan moneter yang diperoleh berdasarkan hasil estimasi terhadap persamaan empiris Taylor Rules. Hasil estimasi Taylor Rules tersebut adalah hasil estimasi dari modifikasi persamaan Taylor Rules 
klasik yang dikenal sebagai interest smoothing rules sebagai berikut (Clarida, Galli,Gertler, (1997) dalam Juhro, (2009):

$i_{t}=0.8 i_{t-1}+0.2\left[6+1.1\left(\pi_{t}-\pi_{t}^{*}\right)+0.4\left(y_{t}-y_{t}^{*}\right)\right]$

Dimana:

$i_{t}=$ Tingkat bunga kebijakan moneter yang optimal

$\pi_{t}=$ Inflasi aktual

$\pi_{t}^{*}=$ Target inflasi

$y_{t}=$ PDB aktual

$y_{t}^{*}=$ PDB potensial yang dihitung menggunakan Hodrick-Prescot Filter

Selanjutnya berdasarkan hasil estimasi yang tersebut, maka dapat diketahui suku bunga yang disarankan oleh Taylor Rules. Sedangkan stance kebijakan moneter adalah selisih antara suku bunga aktual dengan tingkat bunga yang diperoleh berdasarkan Taylor Rules. Beberapa ekonom menggunakan bentuk yang berbeda sebagai ukuran stance kebijakan moneter yang berbasiskan Taylor Rules ini. Penelitian ini menggunakan dummy variabel sebagai cerminan stance kebijakan moneter ketat atau longgar. Dalam hal ini, selisih suku bunga aktual dalam kisaran +/- 25 bps dianggap mencerminkan stance kebijakan normal, sementara selisih lebih besar/kecil dari kisaran tersebut mencerminkan stance kebijakan yang cenderung ketat/longgar.

\section{HASIL DAN ANALISIS}

Sebelum dilakukan estimasi model empiris dan pengujian hipotesis, untuk menguji keberadaan dan dampak resiko dalam mekanisme transmisi kebijakan moneter melalui jalur kredit perbankan di Indonesia, dilakukan pengujian terhadap kelayakan data yang digunakan untuk diuji dalam model empiris yang dispesifikasi. Pengujian yang dilakukan adalah uji akar unit, uji keberadaan kointegrasi atau hubungan dalam keseimbangan jangka panjang antara kredit dan PDB. Pengujian stasioneritas data dan uji kointegrasi memberikan hasil bahwa kredit dan PDB berkointegrasi, sehingga analisis dengan menggunakan model Error Correction Model (ECM) dapat digunakan. Berdasarkan hasil uji kointegrasi menunjukan bahwa ketiga jenis kredit (konsumsi, modal kerja, dan investasi) memiliki hubungan jangka panjang dengan perekonomian. Dengan demikian, terdapat hubungan jangka panjang antara kredit perbankan dengan perkembangan perekonomian. Hasil analisis ini juga menjustifikasi keberadaan dampak ekonomi dari kredit perbankan. 
Tahapan selanjutnya adalah melakukan analisis hubungan antara risiko dengan dinamika jangka pendek kredit perbankan. Kemudian, berdasarkan dampak interaksi antara stance kebijakan moneter dengan variabel risiko, dilakukan analisis keberadaan jalur risiko dalam mekanisme transmisi kebijakan moneter di Indonesia. Hasil estimasi Vector Error Correction Model(VECM) menyimpulkan bahwa kredit bukan merupakan variabel yang weakly exogenous terhadap PDB, sehingga terdapat feedback yang terjadi dari perubahan kredit terhadap dinamika PDB. Terkait dengan fokus penelitian ini, hanya temuan empiris mengenai endogeneity dari kredit yang akan diulas secara lebih mendalam, sebagaimana disampaikan pada Tabel 1.

Dari Tabel 1 dapat dilihat bahwa seluruh koefisien penyesuaian jangka pendek menuju keseimbangan jangka panjang (ECT/Error Correction Term) dalam ketiga model kredit menunjukan tanda negatif dan signifikan pada tingkat keyakinan 99\%. Hasil ini menunjukan

\begin{tabular}{|c|c|c|c|}
\hline Independen Variabel & $\begin{array}{l}\text { Kredit Investasi } \\
\text { [Dlog(CR_INV)] }\end{array}$ & $\begin{array}{l}\text { Kredit Modal Kerja } \\
\text { [Dlog(CR_MK)] }\end{array}$ & $\begin{array}{l}\text { Kredit Konsumsi } \\
\text { [Dlog(CR_KON)] }\end{array}$ \\
\hline $\mathrm{ECT}(\alpha)$ & $\begin{array}{c}-0.082055 \\
{[-3.91674]^{* * *}}\end{array}$ & $\begin{array}{c}-0.293294 \\
{[-5.08903]^{* * *}}\end{array}$ & $\begin{array}{c}-0.091933 \\
{[-2.94792]^{\star * *}}\end{array}$ \\
\hline Stance ${ }^{+}$ & $\begin{array}{l}-0.002575 \\
{[-0.21983]}\end{array}$ & $\begin{array}{l}-0.013970 \\
{[-1.20977]}\end{array}$ & $\begin{array}{l}0.012844 \\
{[1.02093]}\end{array}$ \\
\hline Stance- & $\begin{array}{c}0.028623 \\
{[1.99965]^{* *}}\end{array}$ & $\begin{array}{c}0.030163 \\
{[2.43362]^{\star * *}}\end{array}$ & $\begin{array}{c}0.023414 \\
{[1.75151]^{*}}\end{array}$ \\
\hline DD & $\begin{array}{l}-0.001531 \\
{[-1.16145]}\end{array}$ & $\begin{array}{c}-0.002443 \\
{[-1.96550]^{*}}\end{array}$ & $\begin{array}{l}-0.000502 \\
{[-0.38484]}\end{array}$ \\
\hline A & $\begin{array}{c}0.002996 \\
{[0.24890]}\end{array}$ & $\begin{array}{c}0.024078 \\
{[1.89834]^{\star}}\end{array}$ & $\begin{array}{c}0.025623 \\
{[2.08346]^{\star *}}\end{array}$ \\
\hline Stance ${ }^{*} \mathrm{~A}$ & $\begin{array}{l}-0.006795 \\
{[-0.52006]}\end{array}$ & $\begin{array}{c}-0.023959 \\
{[-1.76619]^{\star}}\end{array}$ & $\begin{array}{c}-0.030875 \\
{[-2.39797]^{\star * \star}}\end{array}$ \\
\hline Stance *A & $\begin{array}{c}-0.032355 \\
{[-1.91202]^{\star}}\end{array}$ & $\begin{array}{c}-0.043594 \\
{[-2.45359] * * *}\end{array}$ & $\begin{array}{c}-0.050885 \\
{[-3.18399]^{* * *}}\end{array}$ \\
\hline Stance ${ }^{*}$ DD & $\begin{array}{l}0.001991 \\
{[1.25322]}\end{array}$ & $\begin{array}{c}0.004052 \\
{[2.57037]^{* * *}}\end{array}$ & $\begin{array}{c}0.000966 \\
{[0.58502]}\end{array}$ \\
\hline Stance $e^{-} \mathrm{DD}$ & $\begin{array}{c}-0.003427 \\
{[-1.86661]^{\star}}\end{array}$ & $\begin{array}{c}-0.003327 \\
{[-2.03648]^{* *}}\end{array}$ & $\begin{array}{l}-0.001984 \\
{[-1.09173]}\end{array}$ \\
\hline $\begin{array}{l}\mathrm{R}^{2} \\
\text { F-test }\end{array}$ & $\begin{array}{c}0.406906 \\
3.185347^{* * *}\end{array}$ & $\begin{array}{c}0.523314 \\
5.097017^{* * *}\end{array}$ & $\begin{array}{c}0.339990 \\
2.391671 * * *\end{array}$ \\
\hline
\end{tabular}


bahwa model yang digunakan cukup stabil dan sesuai dengan pondasi teoritis. Koefisien ECT untuk dinamika jangka pendek log PDB juga menunjukan hasil yang positif dan signifikan. Sementara itu, dalam perspektif goodness of fit permodelan, koefisien determinasi yang menunjukan nilai antara 0.33 sampai 0.52 cukup baik untuk model yang menggunakan data first difference. Hasil uji F-statistik juga menunjukan semua persamaan hasil estimasi signifikan pada tingkat keyakinan 99 persen.

\subsection{Dampak Perilaku Risiko pada Dinamika Kredit Jangka Pendek}

Hasil perhitungan dampak parsial variabel perilaku risiko pada dinamika kredit dalam jangka pendek dilihat pada Tabel 2. Hasil perhitungan dan pengujian statistik menunjukan bahwa pada saat kebijakan moneter longgar terdapat pengaruh yang signifikan dari persepsi

\begin{tabular}{|c|c|c|c|}
\hline \multicolumn{4}{|c|}{$\begin{array}{c}\text { Tabel } 2 . \\
\text { Dampak Perilaku Risiko pada Dinamika Kredit Jangka Pendek }\end{array}$} \\
\hline \multicolumn{2}{|c|}{ Stance Kebijakan Moneter Ketat } & Standar error & t-hitung \\
\hline$\frac{\partial C R^{I N V}}{\partial A}$ & -0.003799 & 0.00526 & -0.72224 \\
\hline$\frac{\partial C R^{K M K}}{\partial A}$ & 0.000119 & 0.00568 & 0.0205951 \\
\hline$\frac{\partial C R^{K O N}}{\partial A}$ & -0.005252 & 0.00504 & -1.04026 \\
\hline$\frac{\partial C R^{I N V}}{\partial A}$ & 0.00046 & 0.00098 & 0.469388 \\
\hline$\frac{\partial C R^{K M K}}{\partial A}$ & -0.00243 & 0.00105 & $-2.32667 * *$ \\
\hline$\frac{\partial C R^{K O N}}{\partial A}$ & 0.000464 & 0.0093 & 0.498925 \\
\hline \multicolumn{4}{|c|}{ Stance Kebijakan Moneter longgar. } \\
\hline$\frac{\partial C R^{I N V}}{\partial A}$ & -0.029359 & 0.01212 & $-2.42236 * * *$ \\
\hline$\frac{\partial C R^{K M K}}{\partial A}$ & -0.019516 & 0.01322 & -1.47625 \\
\hline$\frac{\partial C R^{K O N}}{\partial A}$ & -0.025262 & 0.0119 & $-2.12286 * *$ \\
\hline$\frac{\partial C R^{I N V}}{\partial A}$ & -0.00496 & 0.00118 & $-4.20169 * * *$ \\
\hline$\frac{\partial C R^{K M K}}{\partial A}$ & -0.005770 & 0.0012 & $-4.80833 * * *$ \\
\hline$\frac{\partial C R^{K O N}}{\partial A}$ & -0.00249 & 0.00098 & $-2.53673 * * *$ \\
\hline
\end{tabular}


risiko pelaku ekonomi sektor perbankan (A) dan tingkat risiko sektor perbankan (DD) terhadap dinamika kredit jangka pendek yang disalurkan oleh sektor perbankan (kecuali dampak variabel A untuk Kredit Modal Kerja). Pada saat kebijakan moneter ketat hanya pengaruh variabel tingkat risiko sektor perbankan dalam model kredit modal kerja yang signifikan. Hasil ini mengkonfirmasi bahwa dalam jangka pendek terdapat pengaruh yang signifikan dari variabel persepsi risiko pelaku ekonomi dan tingkat risiko sektor perbankan pada dinamika kredit perbankan di Indonesia.

Selanjutnya, berdasarkan arah koefisien dari hasil estimasi yang lolos uji statistik, variabel persepsi risiko pelaku ekonomi di sektor perbankan memiliki dampak negatif dan signifikan untuk dua jenis kredit (kredit investasi dan kredit konsumsi). Secara ekonomi, pada saat berinteraksi dengan stance kebijakan moneter longgar, jika terjadi kenaikan persepsi risiko pelaku ekonomi di sektor perbankan, hal tersebut akan menurunkan persentase perubahan kredit yang disalurkan untuk kedua jenis kredit tersebut, ceteris paribus. Implikasi hasil temuan ini adalah perlunya pemahaman arah pergerakan tingkat persepsi risiko pelaku ekonomi di sektor perbankan oleh pengambil kebijakan moneter saat menjalankan kebijakan moneter yang ekspansif, karena jika terjadi peningkatan persepsi risiko pelaku ekonomi saat kebijakan moneter yang dijalankan ekspansif, maka dampaknya akan mereduksi atau bahkan membalikan arah dampak kebijakan moneter yang dijalankan terhadap perekonomian melalui penurunan ekspansi kredit.

Selanjutnya, variabel tingkat risiko sektor perbankan (yang berinteraksi dengan stance kebijakan moneter longgar) memiliki arah pengaruh yang negatif dan signifikan, yang berarti bahwa pada saat berlaku kebijakan moneter yang ekspansif, jika semakin rendah risiko sektor perbankan (DD naik), akan menyebabkan turunnya persentase pertumbuhan kredit perbankan yang disalurkan pada ketiga jenis kredit, ceteris paribus. Implikasi temuan empiris ini tidak sesuai dengan hasil analisis teoritis yang dilakukan pada penelitian ini. Fenomena ini membutuhkan kajian yang lebih dalam untuk penjelasannya. Penjelasan sementara dari kondisi ini adalah interaksi risiko sektor perbankan yang pro-siklikal (+) dengan kebijakan moneter yang bersifat kontrasiklikal (-), menyebabkan pembalikan arah dari dampak positif penurunan risiko sektor perbankan terhadap pertumbuhan kredit.

Argumen awal yang mendukung penyebab terjadinya kondisi tersebut adalah sebagai berikut. Pertama, adanya anomali dalam industri perbankan Indonesia, dimana walaupun perbankan Indonesia cenderung tidak efisien dan memiliki tingkat risiko tinggi, namun tetap memiliki margin keuntungan yang cukup tinggi. Kedua, terkait dengan isu persistensi ekses likuiditas dan perilaku pro-siklikal kredit yang disalurkan oleh sektor perbankan (Bank Indonesia, 2010). Stance kebijakan moneter longgar (forward looking) merupakan sinyal bagi pelaku 
perbankan tentang arah pergerakan perekonomian yang cenderung memburuk. Sehingga pelaku ekonomi di sektor perbankan cenderung tidak melakukan ekspansi kredit, melainkan mempertahankan jumlah likuiditas dalam bentuk risk free portfolio yang likuid. Ketiga, hasil temuan empiris terkait perilaku persaingan dalam industri perbankan di Indonesia (Ariefianto, 2010). Penelitian ini menemukan bahwa bank yang memiliki rasio non performing loan (NPL) tinggi, yang berarti pada saat nilai DD nya rendah (risiko tinggi), cenderung melakukan ekspansi kredit untuk menurunkan rasio NPL yang dimilikinya.

Kecuali untuk dampak risiko sektor perbankan pada kredit modal kerja, dampak variabel risiko tidak signifikan terhadap dinamika jangka pendek kredit yang disalurkan perbankan saat kebijakan moneter ketat. Penjelasan untuk kondisi ini adalah bahwa kebijakan moneter yang kontra siklikal mengindikasikan perekonomian yang sedang booming saat kebijakan yang dijalankan ketat, sedangkan persepsi risiko pelaku ekonomi dan tingkat risiko di sektor perbankan cenderung rendah pada saat perekonomian sedang dalam kondisi booming. Akibatnya, jika terjadi kenaikan persepsi risiko pelaku ekonomi dan tingkat risiko di sektor perbankan pada saat kondisi ekonomi dalam keadaan perekonomian baik, hal tersebut cenderung tidak mempengaruhi dinamika kredit jangka pendek yang disalurkan oleh sektor perbankan. Hasil ini mengindikasikan bahwa pengaruh perilaku risiko memiliki dampak yang tidak linier pada saat kebijakan moneter ketat, atau bisa diduga perilaku risiko akan mempengaruhi dinamika kredit jangka pendek jika melewati nilai threshold tertentu (Li dan St-Amant, 2010). Diperlukan penelitian lebih lanjut untuk memperoleh penjelasan dari fenomena tersebut.

Terkait dengan dinamika kredit kerja modal, dampak tingkat risiko di sektor perbankan signifikan, namun dampak persepsi risiko perlaku ekonomi tidak signifikan pada saat kebijakan moneter ketat ataupun longgar. Hal ini kemungkinan dikarenakan kredit modal kerja merupakan kredit yang bersifat hubungan jangka panjang antara bank dengan nasabahnya. Dengan demikian, terjadi relationship banking pada kasus kredit modal kerja, yang menyebabkan persepsi risiko pelaku perbankan terhadap nasabah yang cukup baik dikenalnya bukan merupakan faktor penentu peningkatan penyaluran kredit perbankan. Sebaliknya, tingkat risiko di sektor perbankan merupakan faktor yang mempengaruhi dinamika kredit modal kerja jangka pendek. Hal ini menunjukan adanya indikasi perilaku penawaran kredit yang cenderung turun saat perekonomian sedang dalam tekanan (saat kebijakan moneter yang dijalankan longgar), sedangkan pada saat kebijakan moneter ketat, kenaikan suku bunga kredit perbankan menurunkan tingkat permintaan dari pelaku usaha terhadap pencairan kredit modal kerja.

Secara keseluruhan, berdasarkan hasil temuan dan analisa empiris yang telah dilakukan, tingkat risiko di sektor perbankan (yang berinteraksi dengan stance kebijakan moneter) memiliki dampak yang signifikan dalam dinamika kredit perbankan jangka pendek pada saat kebijakan 
moneter longgar. Pada saat kebijakan moneter ketat, tingkat risiko sektor perbankan hanya signifikan untuk model kredit modal kerja. Persepsi risiko pelaku ekonomi di sektor perbankan tidak signifikan untuk semua jenis kredit pada kondisi stance kebijakan yang ketat, sementara pada saat kebijakan moneter longgar dampaknya signifikan pada kredit konsumsi dan kredit investasi.

\subsection{Dampak Stance Kebijakan Moneter pada Dinamika Kredit Jangka Pendek}

Berdasarkan hasil estimasi yang disampaikan dalam Tabel 1, hasil perhitungan untuk dampak dari stance kebijakan moneter yang berinteraksi dengan variabel perilaku risiko adalah sebagai berikut:

\begin{tabular}{|c|c|c|c|}
\hline & Kredit Investasi & Kredit Modal Kerja & Kredit Konsumsi \\
\hline$\frac{\partial C r^{i}}{\partial \text { Stance }^{+}}$ & $\begin{array}{l}0.004322 \\
(0.00824)\end{array}$ & $\begin{array}{l}-0.00789 \\
(0.00879)\end{array}$ & $\begin{array}{l}-0.00548 \\
(0.00816)\end{array}$ \\
\hline$\frac{\partial C r^{i}}{\partial \text { Stance }^{-}}$ & $\begin{array}{c}-0.01786 \\
(0.00945)^{*}\end{array}$ & $\begin{array}{c}-0.02453 \\
(0.00993)^{* * *}\end{array}$ & $\begin{array}{c}-0.02876 \\
(0.00929)^{\star * *}\end{array}$ \\
\hline
\end{tabular}

Sumber: Hasil Pengolahan Data. *** Signifikan Pada $\alpha 1 \%$, **Signifikan Pada $\alpha 5 \%$, * Signifikan Pada $\alpha 10 \%$

Catatan: Angka dalam kurung adalah standar error hasil perhitungan dampak stance kebijakan moneter (menggunakan nilai rata-rata sample pada masing-masing variabel risiko yang digunakan).

Hasil perhitungan yang disampaikan pada Tabel 3 menunjukan bahwa hanya stance kebijakan moneter longgar yang memiliki pengaruh signifikan pada dinamika kredit perbankan jangka pendek. Berdasarkan arah koefisien yang diperoleh, dampak stance kebijakan moneter longgar pada pertumbuhan kredit perbankan akan lebih rendah dibandingkan dengan pada saat stance kebijakan moneter yang dijalankan tidak longgar. Pada kredit investasi, saat kebijakan moneter longgar, pertumbuhan kredit investasi akan 0.01786 (1.786 persen) lebih rendah dari rata-rata pertumbuhan kredit investasi saat kebijakan moneter tidak longgar. Artinya, jika ratarata pertumbuhan kredit investasi adalah 10 persen pada saat tidak dilakukan kebijakan moneter yang longgar, maka pada saat kebijakan moneter longgar, rata-rata pertumbuhan kredit investasi adalah 8.214 persen, ceteris paribus. Hasil analisis yang sama juga dapat diberlakukan untuk kredit modal kerja dan kredit konsumsi. Pada kredit modal kerja saat kebijakan moneter longgar, pertumbuhan kredit modal kerja akan sebesar 2.453 persen lebih rendah dari rata-rata pertumbuhan kredit modal kerja. Pada kredit konsumsi, saat kebijakan moneter longgar, 
pertumbuhan kredit konsumsi akan sebesar 2.876 persen lebih rendah dibandingkan pertumbuhan kredit konsumsi.

Implikasi dari temuan empiris untuk dampak stance kebijakan moneter ketat adalah kontraksi moneter saat berinteraksi dengan kedua variabel perilaku risiko yang digunakan tidak mempengaruhi dinamika kredit jangka pendek pada ketiga jenis kredit yang disalurkan oleh perbankan. Temuan empiris tersebut tidak sesuai dengan teori bahwa kebijakan moneter yang berinteraksi dengan variabel risiko mempengaruhi dinamika kredit jangka pendek secara signifikan. Temuan tersebut mengindikasikan adanya dampak variabel risiko yang bersifat mengeliminir peran kebijakan moneter dalam mengkontraksi perekonomian. Kebijakan moneter kontraktif dilakukan pada saat perekonomian sedang boom, sedangkan pada saat yang bersamaan persepsi risiko pelaku ekonomi dan tingkat risiko di sektor perbankan cenderung rendah. Akibatnya, pengetatan moneter yang seharusnya mengkontraksi perekonomian melalui jalur kredit menjadi hilang dampaknya. Temuan empiris tersebut mengindikasikan bahwa walaupun bank sentral memberlakukan kebijakan moneter ketat, namun tidak cukup ketat untuk mengkontraksi perekonomian melalui penurunan pertumbuhan kredit perbankan.

Selanjutnya, pada saat kebijakan moneter longgar berinteraksi dengan variabel perilaku risiko memiliki dampak yang negatif dan signifikan untuk ketiga jenis kredit yang disalurkan perbankan. Temuan empiris tersebut seuai dengan teori yang menyatakan adanya dampak signifikan dari kebijakan moneter longgar yang berinteraksi dengan variabel perilaku risiko. Arah hubungan koefisien hasil estimasi menunjukan hubungan yang negatif. Hasil ini menunjukan bahwa kebijakan moneter yang ekspansif tidak mampu meningkatkan pertumbuhan kredit perbankan. Pada saat kebijakan moneter ekspansif (diberlakukan dengan tujuan menstimulasi perekonomian yang berada dalam tekanan), persepsi risiko dari pelaku ekonomi dan tingkat risiko di sektor perbankan cenderung tinggi (rata-ratanya tinggi dalam periode analisis). Akibatnya, pelonggaran kebijakan moneter tidak dapat mendorong peningkatan perekonomian melalui peningkatan kredit perbankan, malah memiliki dampak yang terbalik dengan menurunkan pertumbuhan kredit yang selanjutnya dapat mengkontraksi perekonomian. Temuan ini menunjukkan bahwa pada saat pelonggaran kebijakan moneter dijalankan oleh bank sentral, sebagai usaha untuk menggerakan perekonomian, pelaku ekonomi sektor perbankan cenderung memiliki persepsi risiko yang tinggi. Dengan demikian, perbankan akan menetapkan premi risiko yang tinggi dalam pada tingkat bunga kredit yang ditawarkan sektor perbankan. Dengan kata lain, terjadi rigiditas suku bunga kredit pada saat diberlakukan ekspansi moneter. Penjelasan lain yang dapat disampaikan adalah bahwa adanya kecenderungan pelaku ekonomi di sektor perbankan yang memandang kebijakan moneter longgar sebagai 
indikasi perekonomian sedang mengalami tekanan. Akibatnya, perbankan menjadi semakin selektif dalam mengalokasikan asetnya ke sektor kredit.

\section{KESIMPULAN DAN IMPLIKASI}

Beberapa kesimpulan pokok yang dihasilkan dari penelitian ini adalah bahwa persepsi risiko pelaku ekonomi dan tingkat risiko di sektor perbankan memiliki peran yang signifikan dalam mentransmisikan kebijakan moneter melalui jalur kredit di Indonesia. Variabel persepsi risiko pelaku ekonomi dan tingkat risiko di sektor perbankan saat berinteraksi dengan stance kebijakan moneter menyebabkan pembalikan arah dampak kebijakan moneter yang longgar. Stance kebijakan moneter yang longgar dapat merupakan sinyal bagi pelaku ekonomi di sektor perbankan sebagai kondisi perekonomian sedang menuju perkembangan yang kurang baik. Sebaliknya, stance kebijakan moneter yang ketat untuk mengkontraksi perekonomian melalui jalur kredit perbankan menjadi tidak efektif pada saat berinteraksi dengan variabel persepsi risiko pelaku dan tingkat risiko di sektor perbankan. Hal ini kemungkinan karena adanya dampak perilaku risiko yang bersifat mengeliminir peran kebijakan moneter dalam mengkontraksi perekonomian.

Secara tidak langsung, temuan tersebut juga menyimpulkan bahwa untuk kasus Indonesia, stance kebijakan moneter yang longgar memiliki efek yang menyebabkan pelaku di sektor perbankan cenderung semakin risk averse. Temuan ini berbeda dengan hasil temuan yang dikemukakan oleh Taylor (2009) untuk kasus negara-negara maju, dimana pada negara-negara maju pelonggaran kebijakan moneter menyebabkan pelaku ekonomi di sektor keuangan menjadi semakin risk taker. Analisis juga menunjukkan adanya indikasi dampak yang tidak simetris dari kebijakan moneter ketat dan longgar saat berinteraksi dengan variabel perilaku risiko. Pada saat kebijakan moneter ketat, perilaku risiko cenderung mengeliminir dampak pengetatan moneter terhadap dinamika jangka pendek kredit perbankan. Pada saat kebijakan moneter longgar, penurunan suku bunga kebijakan bank sentral tidak mampu menurunkan suku bunga kredit perbankan agar bisa mendorong peningkatan kredit, sebagai dampak dari perilaku risiko yang cenderung tinggi pada saat kondisi ekonomi dalam tekanan.

Terkait dengan hasil temuan empiris di atas, terdapat beberapa implikasi kebijakan mendasar yang mengarah pada perlunya integrasi kebijakan moneter dan makroprudensial di sektor keuangan, sebagai berikut. Pertama, perlunya Bank Indonesia, sebagai otoritas moneter dan perbankan, untuk memperhitungkan peran persepsi risiko pelaku ekonomi dan tingkat risiko di sektor perbankan dalam perumusan kebijakan moneter dan sistem keuangan di Indonesia. Penelitian ini pada dasarnya dapat dijadikan sebagai salah satu pijakan awal untuk 
memperhitungkan perilaku risiko di sektor keuangan dalam fungsi reaksi kebijakan moneter, yang diharapkan dapat mengatasi isu (pro)siklikalitas perekonomian secara luas. Kedua, dalam konteks untuk mendorong pendalaman dan perluasan peran pasar keuangan, Bank Indonesia perlu melakukan telaah lebih mendalam terkait dengan dampak dinamika di sektor keuangan terhadap efektivitas kebijakan moneter yang dijalankan. Ketiga, sejalan dengan interaksi yang sangat erat antara dinamika (stabilitas) sektor moneter dan sektor keuangan, penguatan koordinasi kebijakan sangat dituntut dari para otoritas terkait dalam menjalankan kebijakan moneter dan kebijakan di sektor keuangan secara terintegrasi.

Pada akhirnya, dapat disampaikan bahwa penelitian ini merupakan penelitian awal. Secara analitis, penelitian awal ini baru menghasilkan bukti keberadaan jalur risiko dalam mekanisme transmisi kebijakan moneter di Indonesia, setidaknya pada saat kebijakan moneter longgar dijalankan. Di luar fakta tersebut masih bersifat black box, mengingat bagaimana proses dan alur dari mekanisme transmisi kebijakan moneter melalui jalur risiko itu sendiri belum mampu dijelaskan oleh hasil temuan ini. Oleh karena itu, ke depan sangat diperlukan penelitian lebih lanjut untuk melihat lebih dalam fenomena yang terdapat di dalam black box tersebut. Di samping itu, penyempurnaan metodologi dapat dilakukan, khususnya terkait dengan pemilihan alternatif indikator perilaku risiko, disagregasi penaksiran indikator perilaku risiko yang mengacu pada individu maupun kelompok bank, serta kemungkinan terdapatnya feedback mechanism di antara kedua variabel perilaku risiko yang digunakan. Penyempurnaan tersebut diharapkan dapat menjawab beberapa pertanyaan empiris yang belum dapat dijelaskan dengan baik dalam penelitian ini. 


\section{DAFTAR PUSTAKA}

Adrian, Tobias, and Hyun Song Shin. (2009), Prices and Quantities in the Monetary Policy Transmission Mechanism, International Journal of Central Banking, 5(4).

Ariefianto, Doddy M, (2010), Perilaku Persaingan Industri Perbankan di Indonesia Pasca Krisis (Analisa Dengan Pendekatan Teori Oligopoli dan Ekonometrika Panel Data Pada Periode 2002 - 2008), Desertasi Doktor Bidang Ilmu Ekonomi. Fakultas Ekonomi Universitas Indonesia. Bank Indonesia, (2010), Response Kebijakan Moneter di Tengah Krisis Global, Laporan Perekonomian Indonesia Tahun 2009, Bank Indonesia.

Bernanke, Ben. S, dan Alan S. Blinder (1988), Credit, Money and Aggregate Demand, The American Economic Review, Vol 78, no. 2. American Economic Association.

Bernanke, Ben. S dan Mark Gertler (1995), Inside the Black Box: The Credit Channel of Monetary

Transmission Mechanism, Journal of Economic Perspectives, Vol 9 No.4. American Economic Association.

Bernanke, Ben S, Mark Gertler dan Simon Gilchrist (1996), The Financial Accelerator and Flight

to Quality, The Review of Economics and Statistics, Vol 78.

Bodie, Zvi, Alex Kane dan Alan J. Marcus (2009),

Investment $8^{\text {th }}$ Ed. Mc Graw-Hill International, Singapore.

Borio, Claudio dan Haibin Zhu (2008), Capital Regulation, Risk Taking and Monetary Policy: A Missing Link in the Transmission Mechanism?, BIS Working Paper no 268. Bank for International Settlement, Basel - Switzerland.

Chan-Lau, Jorge A, dan Amadou N.R. Sy (2007), Distance to Default in Banking: A Bridge too Far?,

Journal of Banking Regulation, Vol 9 No. 1. Palgrave Mc Milan.

Diamond, Douglas W, dan Raghuram G. Rajan, (2006), Money in Theory of Banking, The American Economic Review, Vol 96 No.1, American Economic Association.

Diamond, Douglas W, dan Raghuram G. Rajan, (2001), Liquidity Creation and Financial Fragility:

A Theory of Banking, The Journal of Political Economy, Vol. 109 No. 2. The University of Chicago Press.

Diamond, Douglas W, dan Raghuram G. Rajan, (2000), A Theory of Bank Capital, The Journal of Finance Vol 55 No. 6, American Finance Association. 
Disyatat, Piti (2010), Bank Lending Channel Revisited, BIS Working Paper No. 297. BIS Monetary Policy Department, Basel-Switzerland.

Enders, W., (2004), Applied Econometric Time Series, New York: John Wiley \& Sons

Escandon, Julio R, Alejandro Diaz-Bautista, (2000), A Simple Dynamic Model of Credit and Aggregate Demand, El Collegio De La Frontera Norte, Working Paper No.18..

Freixas, Xavier dan Jose Jorge, (2008). The Role of Interbank Market in Monetary Policy: A Model with Rationing, The Journal of Money Credit and Banking, September.

Gambacorta, Leonardo (2009), Monetary Policy and the Risk Taking Channel, BIS Quarterly Review, Desember 2009. Bank for International Settlement, Basel.

Goeltom, Miranda. S, Solikin M. Juhro dan Firman Mochtar (2009), Indonesian Monetary Policy Transmission Mechanisms and the Role of Risk Perception, Research Notes, Bank Indonesia, March.

Goodhart, C.A.E dan D.P. Tsomocs, (2007), Analisys of Financial Stability, Bank of Canada Conference "Developing a Framework to Asses Financial Stability" Ottawa, Canada, 7-8 November.

Juhro, Solikin M. (2009),

Telaah Policy Rules di Indonesia, Research Notes, Bank Indonesia, Maret.

Mishkin, Frederick S. (2009), Is Monetary Policy Effective During Financial Crisis?, NBER Working Paper No. 14678.

Merton, Robert C. (1974), On the Pricing of Corporate Debt: the Risk Structure of Interest Rates, Journal of Finance

Vol. 29.

Nier, Erlend dan Lea Zicchino, (2008), Bank Losses, Monetary Policy and Financial Stability-

Evidence From Interplay in Panel Data,

IMF Working Paper WP/08/232.

Li, Fuchun dan Pierre St-Amant (2010),

Financial Stress, Monetary Policy and Economic Activty, Bank of Canada Working Paper 201012, May.

Taylor, John B. (2009), The Financial Crisis and Monetary Response: An Empirical Analysis of What Went Wrong, NBER Working Paper Series No. 14631.

Tieman, Alexander F, dan Andrea M Maechler, (2009), The Real Effects of Financial Sector Risk, IMF Working Paper WP/09/198, IMF Washington.

Van Den Heuvel, Skander J, (2007).

The Bank Capital Channel of Monetary Policy, Bank of Canada Conference "Developing a Framework to Asses Financial Stability" Ottawa, Canada, 7-8 November. 
Vassalaou, Maria dan Yuhang Xing (2004), Default Risk in Equity Return, The Journal of Finance, Vol 59 No, 2. April.

Wooldridge, Jeffery M. (2006), Introductory Ecoometrics: A Modern Approach $3^{\text {rd }}$ Ed. Thompson South-Western Publishing. USA. 